\title{
MOLECULAR EVOLUTION OF GPCRS GLP1/GLP1 receptors
}

Jong-lk Hwang, Seongsik Yun, Mi Jin Moon, Cho Rong Park and Jae Young Seong

Graduate School of Medicine, Korea University, Seoul 136-705, Republic of Korea

Correspondence should be addressed to $J$ Y Seong

Email

jyseong@korea.ac.kr

\begin{abstract}
Glucagon-like peptide 1 (GLP1) is an intestinal incretin that regulates glucose homeostasis through stimulation of insulin secretion from pancreatic $\beta$-cells and inhibits appetite by acting on the brain. Thus, it is a promising therapeutic agent for the treatment of type 2 diabetes mellitus and obesity. Studies using synteny and reconstructed ancestral chromosomes suggest that families for GLP1 and its receptor (GLP1R) have emerged through two rounds $(2 R)$ of whole genome duplication and local gene duplications before and after 2R. Exon duplications have also contributed to the expansion of the peptide family members. Specific changes in the amino acid sequence following exon/gene/genome duplications have established distinct yet related peptide and receptor families. These specific changes also confer selective interactions between GLP1 and GLP1R. In this review, we present a possible macro (genome level)- and micro (gene/exon level)-evolution mechanisms of GLP1 and GLP1R, which allows them to acquire selective interactions between this ligand-receptor pair. This information may provide critical insight for the development of potent therapeutic agents targeting GLP1R.
\end{abstract}

$\begin{aligned} & \text { Key Words } \\ & \text { - evolution } \\ & \text { - exon } \\ & \text { - GLP1 } \\ & \text { - GLP1R } \\ & \text { - G protein-coupled receptor } \\ & \text { - genome } \\ & \text { - gene } \\ & \text { - duplication }\end{aligned}$

Journal of Molecular Endocrinology (2014) 52, T15-T27

\section{Introduction}

Glucagon-like peptide 1 (GLP1) is a gastrointestinal peptide hormone that stimulates insulin secretion from pancreatic $\beta$-cells and promotes insulin synthesis (Schmidt et al. 1985, Fehmann \& Habener 1992, Moon et al. 2011). GLP1, encoded by the glucagon (GCG) gene, is produced by tissue-specific posttranslational proteolytic processing of a large precursor containing three independent peptides GCG, GLP1, and GLP2 (Mojsov et al. 1986, Kieffer \& Habener 1999). Intestinal L-cells produce mature GLP1 and GLP2 but not GCG, while pancreatic $\alpha$-cells produce mature GCG but not GLP1 and GLP2. Biologically active GLP1s consist of 30 or 31 amino acids, both of which have similar bioactivities and overall metabolism, although most GLP1 secreted from the gut is C-terminally amidated and 30 amino acids in length (Mojsov et al.
1990). GLP1, secreted from L-cells in response to food intake, regulates blood glucose level by inducing insulin secretion in a glucose concentration-dependent manner, while it suppresses GCG release from pancreatic $\alpha$-cells (Fehmann et al. 1995, Hansotia \& Drucker 2005). The glucose-dependent action of GLP1 has potential for the treatment of diabetes mellitus because it does not cause hypoglycemia under normal plasma glucose concentration conditions (Baggio \& Drucker 2002, Nauck et al. 2002). In addition to its incretin activity, GLP1 stimulates proliferation and differentiation of pancreatic $\beta$-cells (Xu et al. 1999, Drucker 2003, Li et al. 2003). GLP1 is also produced in neurons of the brainstem and is transported through axonal networks to diverse brain regions such as the cerebral cortex, hypothalamus, and thalamus 
(Vrang et al. 2007, Hisadome et al. 2010). In the brain, GLP1 is known to promote satiety by regulating appetite and food intake, resulting in body weight loss (Zander et al. 2002). GLP1 is also involved in neurite outgrowth and spatial learning ability in the central nervous system (During et al. 2003, Perry et al. 2007).

The physiological activities of GLP1 occur by interaction with the GLP1 receptor (GLP1R), which is expressed in pancreatic islets, brain, heart, kidney, and the gastrointestinal tract (Graziano et al. 1993, Wei \& Mojsov 1995, Alvarez et al. 2005). Ligand-stimulated receptors increase intracellular cAMP by coupling to adenylate cyclase through the $\mathrm{G}_{\mathrm{s}}$ protein (Drucker et al. 1987, Fehmann et al. 1995) and by elevating cytosolic calcium through activation of the $\mathrm{G}_{\mathrm{q}}$-mediated PLC $\beta$ pathway (Wheeler et al. 1993). However, one study reports that calcium responses may be secondary effects related to increased intracellular cAMP (Kang et al. 2001).

GLP1R is a member of the secretin receptor (SCTR)-like (class B1) family of G protein-coupled receptors (GPCRs) that comprise 15 human receptors for 20 corresponding peptide ligands (Harmar 2001, Hwang et al. 2013). As the SCTR-like receptors and their peptide ligands share similar structural features, they are likely to have emerged through gene/genome duplications from common ancestors. Duplicated receptors and peptides have undergone sequence changes during evolution, leading to diversification of their physiological functions (Acharjee et al. 2004, Kim et al. 2012). Specific diversification of peptides, i.e. conservation within orthologs but variation among paralogs, could confer selective interaction of a peptide with the cognate receptor, allowing discrimination by paralogous receptors (Wang et al. 2004, Li et al. 2005, Cho et al. 2007, Lee et al. 2009). This review describes the influence of genome/gene/exon duplications on the emergence of GLP1 and GLP1R, and the specific changes allowing selective interaction between this ligandreceptor pair.

\section{Evolution of SCTR-like GPCRs and their peptide ligands}

Since the first identification of SCTR that exhibits amino acid sequence distinct from that of other known GPCRs (Ishihara et al. 1991), the SCTR-like receptors including GLP1R have been identified in a variety of invertebrate and vertebrate species (Harmar 2001). SCTR-like GPCRs can be categorized into the following: i) corticotropinreleasing hormone receptor (CRHR) subfamily, ii) calcitonin receptor (CALCR) subfamily, iii) parathyroid hormone receptor (PTHR) subfamily, iv) GCG receptor (GCGR) subfamily including GCGR, GLP1R, GLP2R, and glucosedependent insulinotropic polypeptide receptor (GIPR), and $v$ ) growth hormone-releasing hormone receptor (GHRHR) subfamily including GHRHR, SCTR, vasoactive intestinal peptide receptor 1 (VIPR1), VIPR2, and pituitary adenylate cyclase-activating polypeptide receptor (ADCYAP1R1) (Harmar 2001, Fredriksson et al. 2003, Oh et al. 2006, Hwang et al. 2013).

Although GLP1 and GLP1R are found only in vertebrates (Sherwood et al. 2000, Irwin \& Prentice 2011), the genome history of SCTR-like GPCRs and their peptide ligand genes date back to early bilaterian ancestors (Harmar 2001, Cardoso et al. 2006). Recent advances in bioinformatic tools and public genome databases for a wide range of animal kingdoms have allowed identification of additional members and exploration of evolutionary history of the SCTR-like family (Cardoso et al. 2006, Nordstrom et al. 2008, Irwin \& Prentice 2011, Hwang et al. 2013, Park et al. 2013). CRHR and CALCR subfamilies are likely the earliest members of this family as they are present in most deuterostomes as well as in the protostomes Caenorhabditis elegans and Caenorhabditis briggsae (nematode) and Drosophila melanogaster and Anopheles gambiae (arthropod) (Harmar 2001, Cardoso et al. 2006). In addition, D. melanogaster contains genes that are phylogenetically closest to CRH and CALC out of all the peptide family members (Hewes \& Taghert 2001, Hwang et al. 2013). Short-range linkage analysis between protostome and deuterostome homologous regions that contain SCTR-like receptor genes demonstrated the existence of common neighbor families for SCTR-like receptor genes (Cardoso et al. 2006). Recently, the presence of protostomian PTHR-like has been demonstrated (Mirabeau \& Joly 2013). Thus, it is plausible that the ancestors for the CRHR (CRHR1), CALCR, and PTHR subfamilies have emerged during early metazoan evolution before the divergence of deuterostomes and protostomes. In the deuterostome lineage, besides the CRHR, CALCR, and PTHR gene subfamilies, the GCGR and GHRHR subfamily genes occurred during chordate and vertebrate evolution. The amphioxus (Branchiostoma floridae, a representative of the cephalochordates) genome contains the CRHR, CALCR, and PTHR subfamily genes, but lacks the GCGR and GHRHR subfamily genes (Nordstrom et al. 2008, Hwang et al. 2013). Blast search of the tunicate (Ciona intestinalis, a representative of the urochordates) genome shows the emergence of the GCGR subfamily genes together with the CRHR, CALCR, and PTHR subfamily genes (Cardoso et al. 2006,

Published by Bioscientifica Ltd 
Hwang et al. 2013). However, no GHRHR subfamily genes have been identified in tunicates. In lampreys (Petromyzon marinus, a basal vertebrate agnathan), a VIPR-like gene, a member of the GHRHR subfamily genes was identified (Ng et al. 2012, Hwang et al. 2013). Thus, lamprey has SCTR-like receptors belonging to all five subfamilies.

Unlike the receptor genes, the $S C T$-like peptide family genes were not retrieved from nonvertebrates (protostome and early deuterostome), likely due to the considerable variation in short peptide sequences of these species (Cardoso et al. 2010, Hwang et al. 2013). In basal vertebrate lamprey, however, several peptide genes such as adrenomedullin, GHRH, VIP, ADCYAP1, and GCG were observed (Cardoso et al. 2010, Hwang et al. 2013). Despite the presence of three CRHR-like genes, the corresponding $\mathrm{CRH}$-like peptide genes were not found in lamprey. As in other vertebrates, the lamprey VIP, ADCYAP1, and GCG genes may encode two or more mature peptides ( $\mathrm{Ng}$ et al. 2012, Hwang et al. 2013). As the mature peptides have similarities in their amino acid sequences on consecutive exons, these peptides are proposed to have emerged through exon duplication events during early vertebrate evolution (Irwin et al. 1997, Sherwood et al. 2000, Irwin \& Prentice 2011).

\section{Gene/genome duplications contribute to the emergence of GLP1 and GLP1R}

Gene families with large numbers of paralogs are established through evolutionary processes, such as gene/genome duplications followed by gene alterations or losses (Abi-Rached et al. 2002, Larhammar et al. 2002, Holland 2003, Santini et al. 2003, Vienne et al. 2003, Kim et al. 2011, Hwang et al. 2013). In particular, two rounds (2R) of whole genome duplication during early vertebrate evolution are considered to mainly contribute to expansion of the family members. In addition, local gene duplications on a chromosome before or after 2R further diversify the family members (Hwang et al. 2013). Rapid and vast accumulation of genome sequence information of many representative taxa allows synteny-based genome comparisons and facilitates the analyses of origins and relationships of family members (Lee et al. 2009, Kim et al. 2011, 2012). Furthermore, entire genome comparisons between evolutionarily distinct taxa have led to reconstruction of hypothetical ancestral chromosomes of early vertebrates or chordates (Nakatani et al. 2007, Putnam et al. 2008). Nakatani et al. (2007), constructed hypothetical post-2R gnathostome ancestor chromosomes (GACs AO-J1 linkage groups) that were derived from
pre-2R 10-13 vertebrate ancestral chromosomes (VACs A-f). Deducing locations of the gene family members to reconstructed chromosomes also provides fast and relatively accurate tools to trace gene origins (Yegorov \& Good 2012, Hwang et al. 2013).

\section{Emergence of GLP1R}

When all SCTR-like genes were assigned on reconstructed pre-2R VAC as proposed by Nakatani et al. (2007), most genes, except for the GCGR subfamily, were found to be on the $V A C E$ linkage group consisting of four paralogons as represented in human chromosomes 2 (GACEO), 7 and 3 (GAC E1), 17 (GAC E2), and 12 (GAC E3) (Fig. 1). GCGR subfamily members are on different GACs (Hwang et al. 2013), which is likely due to some ancestral linkage groups being inaccurately reconstructed because of massive chromosome rearrangements in these regions, or alternatively, the gene underwent a single gene translocation that caused it to move from its authentic chromosomal fragments before or after $2 \mathrm{R}$. Synteny result suggests that consecutive local duplications of the SCTR-like ancestor on VAC E generated GCGR and GHRHR ancestral genes (Fig. 1). Neighbor gene analyses of SCTR-like-containing genome fragments of the amphioxus, tunicate, and lamprey may further support this possibility. For example, 15 amphioxus SCTR-like genes are located on ten different scaffolds. Many neighbor genes in these scaffolds well pair with those on human chromosomes having the SCTR family genes (Fig. 1). In tunicates, CRHR and CALCR are closely located on chromosome 3 with neighbors that are also found on VACE. The PTHR-like on a small scaffold also shares a common neighbor gene on VAC E. Two GCGR-like genes reside closely on chromosome 3 . Interestingly, their adjacent neighbors are shown on both VAC E and GCGR family gene-containing chromosomes (Fig. 1). In lamprey, although the sizes of scaffolds containing SCTR-like genes are small so as to have very limited numbers of neighbors or no neighbors, most neighbors in these scaffolds are mapped on VAC E (Fig. 1). Interestingly, one scaffold harboring the GCGR gene subfamily has a neighbor that localizes on $V A C E$, while another has a neighbor on GCGR family gene-containing chromosomes. Together, these results obtained from chordates and basal vertebrate lamprey indicate a consecutive emergence of SCTR-like GPCRs during deuterostome evolution.

The $2 \mathrm{R}$ and local duplications, followed by sequences change and gene loss, have established osteichthyan ancestral genes for SCTR-like GPCRs and their peptide ligand (Hwang et al. 2013). Regarding GLP1R, these

Published by Bioscientifica Ltd 


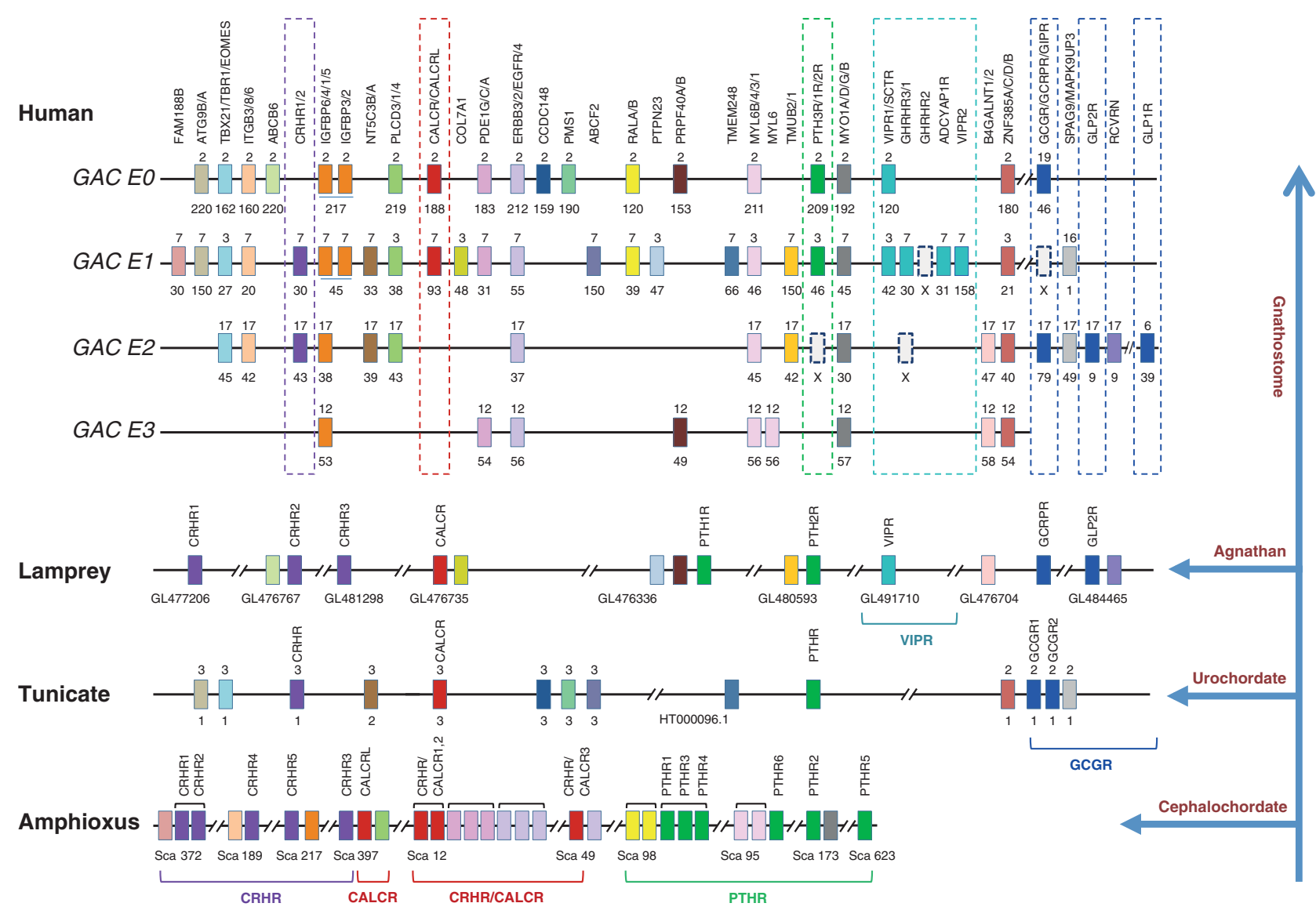

\section{Figure 1}

Conserved synteny for genome fragments containing the SCTR-like family genes. The genomic locations of the human SCTR-like family genes along with their neighbor genes were compared with those of orthologous genes in amphioxus (cephalochordate), tunicate (urochordate), and lamprey (basal vertebrate agnathan). Orthologs and paralogs are aligned on the same column with the same color. Chromosome numbers are indicated above the gene, and gene locations (megabase) are indicated below the gene in human and tunicate. In amphioxus and lamprey, scaffold numbers are shown below the genes. The absence of the gene in humans is indicated

gene/genome duplications contributed to the occurrence of GCGR, GLP1R, GLP2R, GIPR, and GCG-related peptide receptor $(G C R P R)$ genes. GCRPR is a new member found in many vertebrate species but not in mammals (Irwin \& Prentice 2011, Wang et al. 2012, Hwang et al. 2013, Park et al. 2013). The phylogenetic tree of the GCGR subfamily reveals two independent branches for GLP2R and GLP1R, and a branch comprising GCGR, GIPR, and GCRPR subbranches (Fig. 2A). Synteny analysis for GCGR subfamily gene-containing genome fragments of vertebrate species shows that GCGR, GIPR, and GCRPR are on three different paralogons that share common neighbor gene families. Although GCRPR is not found in humans, neighbor gene analysis of other vertebrate species suggests by white boxes with broken lines under which ' $\mathrm{X}$ ' was labeled. Paralogous genes generated by $2 R$ exist on human chromosomes 2,7 (or 3), 17, and 12, which fall into reconstructed linkage groups $G A C E O, E 1, E 2$, and $E 3$ respectively. The GCGR subfamily genes were aligned on different chromosomes as they are on different linkage groups other than GAC Es. Annotations for amphioxus, tunicate, and lamprey SCTR-like family genes are shown in Hwang et al. (2013). In the case of lamprey, chromosome duplication events for generation of paralogous genes cannot be excluded although genes are on the same row.

that GCRPR was likely lost in human chromosome 16 (Fig. 2B). GLP2R is on the same chromosome containing GCGR. Although GLP1R is on different chromosome, it shares neighbor gene family with the GIPR-containing genome fragment. The phylogenetic tree of the GCGR subfamily gene suggests that GLP2R is likely an earliest form of the subfamily, followed by subsequent emergences of GLP1R and an ancestor for GCGR/GIPR/GCRPR. Combined with synteny data, this result raises a possibility that GLP2R, GLP1R, and an ancestor for GCGR/GIPR/ $G C R P R$ arose through local duplication before $2 \mathrm{R}$ while GCGR, GIPR, and GCRPR have emerged through $2 \mathrm{R}$ (Fig. 2C). Interestingly, this receptor duplication scheme is well correlated with that of corresponding peptide

Published by Bioscientifica Ltd 


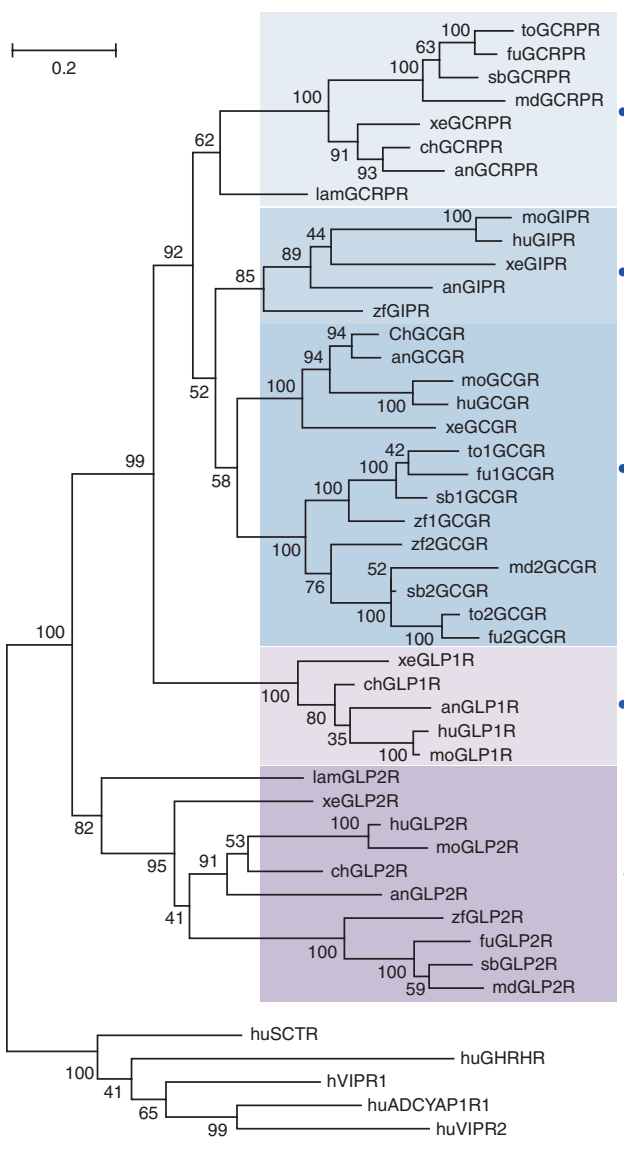

B

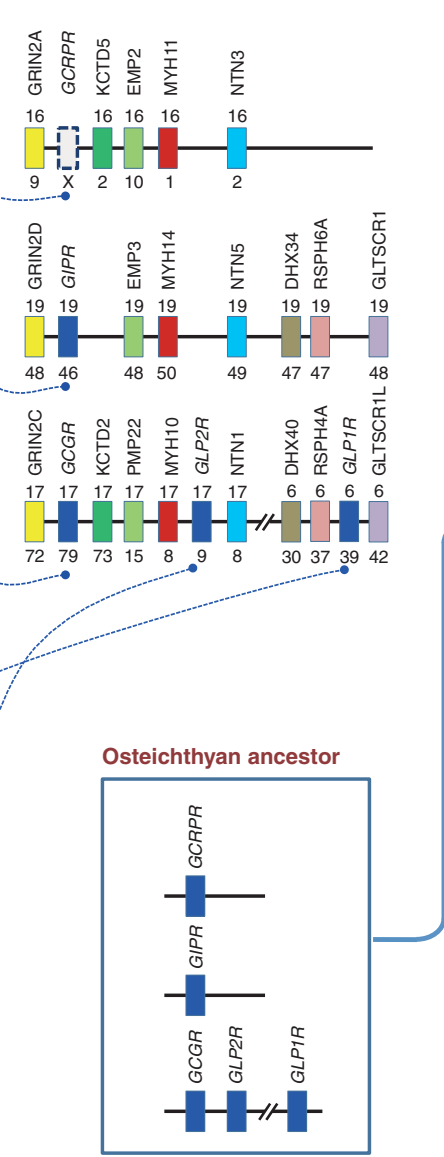

C

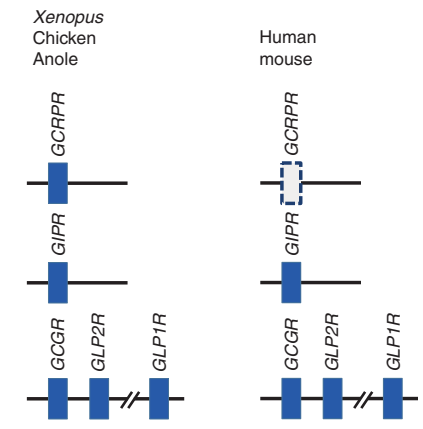

Non-

placental

Tetrapod

\section{Figure 2}

Phylogeny and synteny for the GCGR subfamily genes. (A) Maximum likelihood phylogenetic tree for the GCGR subfamily of human (hu), mouse (mo), chicken (ch), anole lizard (an), Xenopus (xe), zebrafish (zf), medaka (md), fugu (fu), stickleback (sb), tetraodon (to), and lamprey (lam) along with human SCTR, GHRHR, VIPRs, and ADCYAP1R1. The receptor sequences were aligned by using MUSCLE and a tree was constructed with MEGA 5.05. Bootstrap number indicates 100 replicates. (B) Synteny for human genome fragments having the GCGR subfamily genes. Chromosome numbers are

genes. In the peptide genes, GCG-, GLP1-, and GLP2coding exons are duplicated in a single gene GCG. GCG, GIP, and GCRP arose through 2R (Irwin \& Prentice 2011, Wang et al. 2012, Park et al. 2013). After divergence of teleosts and tetrapods, in teleosts GLP1R was lost and $G C G R$ was doubled due to the teleost-specific third round (3R). There are also species-specific losses of genes. For instance, GCRPR in zebrafish and mammals and GIPR in medaka disappeared (Fig. 2C).

\section{Emergence of GLP1}

The majority of genes for SCT-like peptide ligands are located on VAC D. The GHRH and $C R H / U C N$ ancestors are Printed in Great Britain indicated above the gene, and gene locations (megabase) are indicated below the gene. Paralogous genes are aligned on the same column with the same color. (C) Proposed evolutionary history of the GCGR subfamily genes in vertebrates. GLP2R, GLP1R, and GCGR have emerged by local duplication before $2 R$ while GIPR and GCRPR arose by $2 \mathrm{R}$ in an osteichthyan ancestor. After divergence of teleosts and tetrapods, GLP1R disappeared and GCGR were doubled through teleost-specific $3 R$ in teleosts. The absence of the gene in each species is indicated by white boxes with broken lines.

aligned on VAC B where GLP1R is located, while the $G C G$ ancestor is on VAC $E$ where most SCTR-like GPCRs are found. Because the ancestors of this family, the UNC2/3, $C A L C$, and $P T H$, are on VAC $D$, it is postulated that all these peptide members have emerged on $V A C D$ through local duplications. Subsequently, some members may have been translocated to VAC B or E (Hwang et al. 2013). The time of GCG ancestor emergence remains unclear. Although tunicates have two GCGR-like genes, conventional Blast search tools failed to identify any peptide ligand genes for SCTR-like receptors in chordates (Cardoso et al. 2010). This is likely due to considerable amino acid variation within a short sequence of the mature peptide (Cardoso et al. 2010, Hwang et al. 2013). 
Because the lamprey has two $G C G$-like genes, the $G C G$ ancestor is likely to have emerged before the divergence of agnathans and gnathostomes (Hwang et al. 2013).

With regard to the GLP1 family peptides, GCG (GCGGLP1-GLP2), GIP, and a novel GCRP have emerged through 2R (Irwin \& Prentice 2011, Hwang et al. 2013, Park et al. 2013). GCRP was classified as a member of the exendin-4 family in a previous study (Irwin \& Prentice 2011). However, a recent study using phylogenetic analysis and biochemical ligand-receptor activity assays has revealed that GCRP was distinct from exendin-4 as well as other GLP1-related peptides (Park et al. 2013). Synteny analysis of GCG-, GIP-, and GCGR-containing genome fragments reveals similar neighbor genes, flanking these peptide family genes (Irwin \& Prentice 2011). In accordance with this observation, the GCG, GIP, and GCGR genes are located on GAC EO, E2, and E3 respectively (Hwang et al. 2013, Park et al. 2013), suggesting that these three genes are ohnologous to one another. However, the fourth gene was lost before the divergence of tetrapods and teleosts.

In the teleost lineage, the 3R of genome duplication further contributed to emergence of the second form of
GCG and GCGR. However, GLP1R disappeared in this lineage. The pattern of gene loss in teleosts differs by species. For example, zebrafish have lost GCRP and GCRPR, while the medaka lacks GIP and GIPR (Hwang et al. 2013, Park et al. 2013). In the tetrapod lineage, mammals have lost GCRP and GCRPR (Fig. 2C). The absence of GLP1R in teleost fish, in spite of the presence of the GLP1 peptide, remains enigmatic. With regard to the concept of coevolution of the peptide and the receptor, the possibility remains that existing receptors recognize paralogous peptides in place of the missing orthologous partners. For example, fish GLP1 binds fish GCGRs with high affinity (Irwin \& Wong 2005). Thus, it is possible that GLP1 has gained a GCG-like function in teleost fish (Nguyen et al. 1994).

\section{Exon duplication events for GLP1 and related peptides}

Because most vertebrate GCG genes encode GCG, GLP1, and GLP2 on consecutive exons, these three peptides are likely to have emerged through exon duplication events (Fig. 3A). However, the time of exon duplication for GLP1
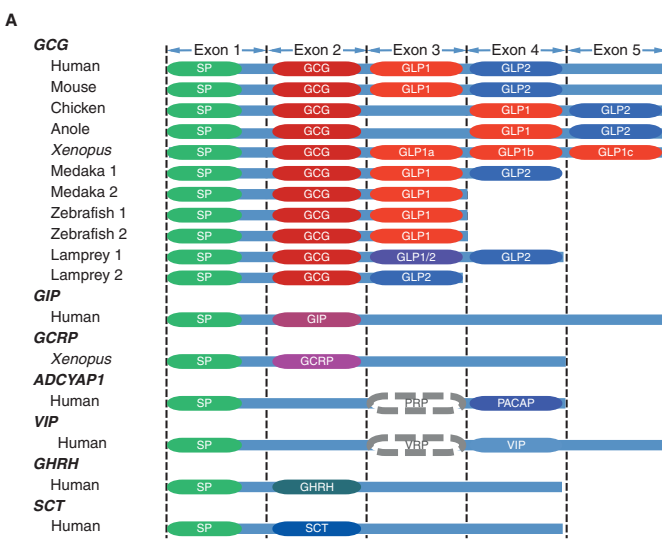

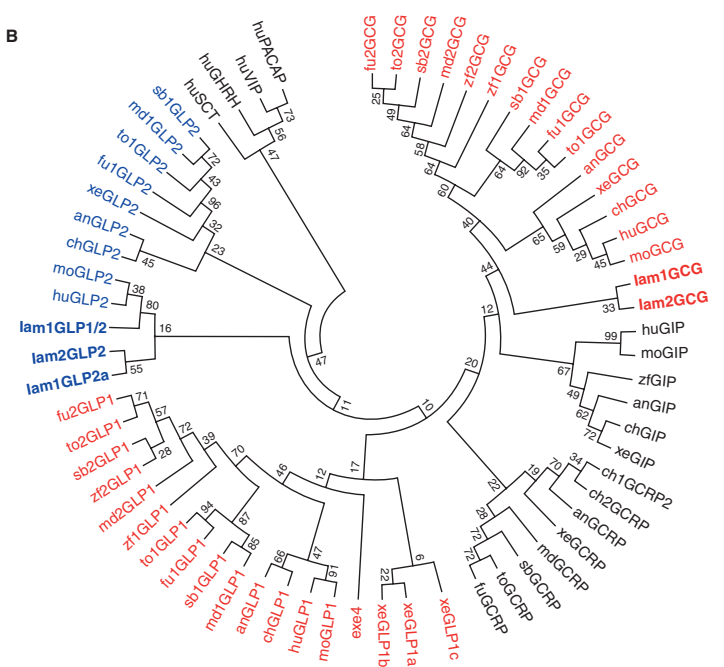

Figure 3

Phylogeny and exon structures of GCG and related peptide genes. (A) Exon structures of the GCG and related genes from various vertebrates and lamprey. In this diagram, as only the open reading frame-encoding exons are counted, the first exon contains the signal peptide (SP) sequence. The exons that do not encode the mature peptide sequence are also shown as simple lines. GCG, GLP1, and GLP2 are encoded by three different exons of the human GCG gene. The Xenopus GCG gene encodes three independent GLP1 peptides as well as GCG and GLP2. The second forms of medaka and zebrafish GCG genes lack GLP2. Location of the mature peptides on the exons of other peptide genes such as GIP, GCRP, ADCYAP1, VIP, SCT, and GHRH is also shown. Nonmammalian ADCYAP1 and VIP encode http://jme.endocrinology-journals.org DOI: 10.1530/JME-13-0137
๑) 2014 Society for Endocrinology Printed in Great Britain
PACAP-related peptide (PRP) and VIP-related peptide (VRP), respectively, while those sequences in human genes are dysfunctional. The vestiges that remained in the human genes are indicated by spaces covered with gray dashed lines. (B) Maximum likelihood phylogenetic tree for GLP1-related peptides of human (hu), mouse (mo), chicken (ch), anole lizard (an), Xenopus (xe), zebrafish (zf), medaka (md), fugu (fu), stickleback (sb), tetraodon (to), and lamprey (lam) along with human SCT, GHRH, VIP, and PACAP are shown. The mature peptide sequences were aligned using MUSCLE, and a bootstrap consensus tree was constructed using MEGA 5.05. Bootstrap numbers represent 100 replicates.

Published by Bioscientifica Ltd 
is unclear (Sherwood et al. 2000). The basal vertebrate lamprey has two GCG-like genes (Irwin et al. 1999). One (lam1GCG) encodes GCG and two GLP2-like peptides (GLP1/2 and GLP2), and the other (lam2GCG) encodes GCG and GLP2. The phylogenetic position of lamGLP1/2 is currently unclear. A previous study using Clustal X-2.1 alignment followed by the neighbor-joining phylogenetic tree indicated that lam1GLP1/2 is more similar to GLP1 than to other related peptides (Hwang et al. 2013), while this study using multiple sequence alignment with high accuracy (MUSCLE) alignment with a maximum likelihood phylogenetic tree shows a close relationship of lam1GLP1/2 with mammalian GLP2 (Fig. 3B). Despite the confusion, this observation suggests that exon duplication events date back to early vertebrate evolution before the divergence of agnathans and gnathostomes. Owing to the short nucleotide sequences of scaffolds (GL481103 and GL477955) harboring the lamprey GCGs, it is still uncertain whether the two lamprey GCGs were generated by genome duplication or local gene duplication. However, as very close relationships between peptides encoded by lam $1 G C G$ and lam2GCG are evident from the phylogenetic tree (Fig. 3B), these two genes may have emerged recently, probably through local duplication. Interestingly, the ADCYAP1 and VIP genes in vertebrates and basal vertebrate lamprey, which are believed to have emerged next to the GCG gene, also encode two mature peptides, and one (PACAP-related peptide (PRP) or VIP-related peptide (VRP)) of these two peptides is similar to GHRH in amino acid sequence (Laburthe et al. 1996, Sherwood et al. 2000, Ng et al. 2012, Hwang et al. 2013). Although the physiological roles of PRP and VRP remain incompletely understood, their interactions with specific receptors have been described in zebrafish and chicken (Wang et al. 2010). In addition, some vertebrate GHRH genes also encode PACAPor VIP-like peptide sequences, although these peptides are likely nonfunctional. It is important to note that the PACAP, VIP, GHRH, and SCT peptide sequences are relatively more closely related to the GLP2 peptide when compared with other related peptides (Fig. 3B). This observation raises a possibility that the ancestor for ADCYAP1, VIP, GHRH, and SCT emerged through local gene duplication of the GLP2-containing ancestral gene before $2 \mathrm{R}$, and that exon duplication events in this ancestor may influence the presence of the two peptides in the ADCYAP1, VIP, and GHRH genes (Fig. 3B). The exon duplication event before $2 \mathrm{R}$ was followed by additional exon duplication in Xenopus of the tetrapod lineage, or exon degeneration after 3R in the teleost lineage. The GCG gene of Xenopus, a representative amphibian, contains two more exons encoding GLP1s. A copy of teleost-specific duplicated GCGs has lost the GLP2 sequence. In zebrafish, both GCGs lack the GLP2 sequence (Fig. 3A).

\section{Specific amino acid sequence changes determine selective ligand-receptor interactions}

GLP1R and its paralogous receptors exhibit high degrees of amino acid sequence identity with one another and share a relatively long N-terminal extracellular domain (ECD) beginning with an $\alpha$-helix followed by four $\beta$-strands forming two antiparallel sheets that are stabilized by disulfide bonds and a salt bridge (Grace et al. 2004, Parthier et al. 2007, Runge et al. 2008, Underwood et al. 2010). Likewise, all peptide ligands for these receptors have typical three-dimensional structures to facilitate receptor binding. GLP1 and its family of peptides consist of 30-40 amino acids which share similarities in amino acid sequence and secondary structure. The structures of the peptides demonstrated by nuclear magnetic resonance and crystallography reveal that the N-terminal six or seven amino acid residues of peptides form a random coil structure where they share more than $70 \%$ amino acid sequence identity, and this is followed by an $\alpha$-helical structure with moderate sequence similarity among the peptides (Thornton \& Gorenstein 1994, Neidigh et al. 2001, Alana et al. 2007, Parthier et al. 2007, Underwood et al. 2010). Some residues with different lengths are extended after the $\alpha$-helix to form flexible regions in the C-terminus, although this region is not necessary for receptor recognition and activation (Hinke et al. 2003, Moon et al. 2010). These peptides form a common local structure, called a helix N-capping motif, to stabilize the helical structure (Neumann et al. 2008). This motif in GLP1 is formed between hydrophobic amino acids Phe- 6 and Val-10, and the polar amino acid Thr-7 through hydrophobic interaction and hydrogen bonding. These interactions are believed to facilitate receptor activation upon ligand-receptor binding (Fig. 4A). While the $\mathrm{N}$-terminus and the first half of the central $\alpha$-helical structures are responsible for interaction with the receptor core domain, the second half of the $\alpha$-helical region binds directly to the ECD of the receptor (Parthier et al. 2007, Underwood et al. 2010, Moon et al. 2012a).

\section{Interaction between peptide $\mathrm{N}$-terminus and the receptor} core domain

Although the GLP1 peptide and receptor families exhibit relatively high sequence similarities and conserved

Published by Bioscientifica Ltd 

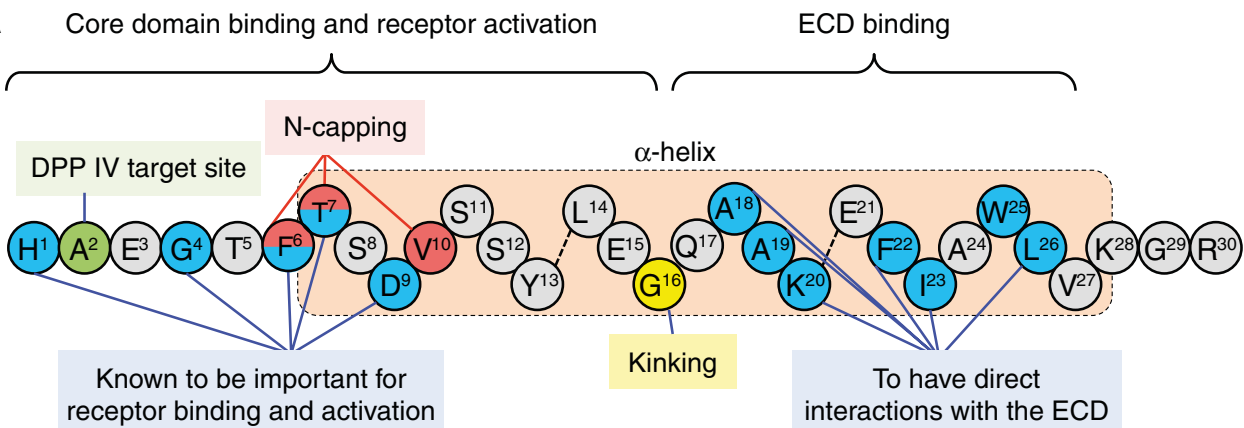

B

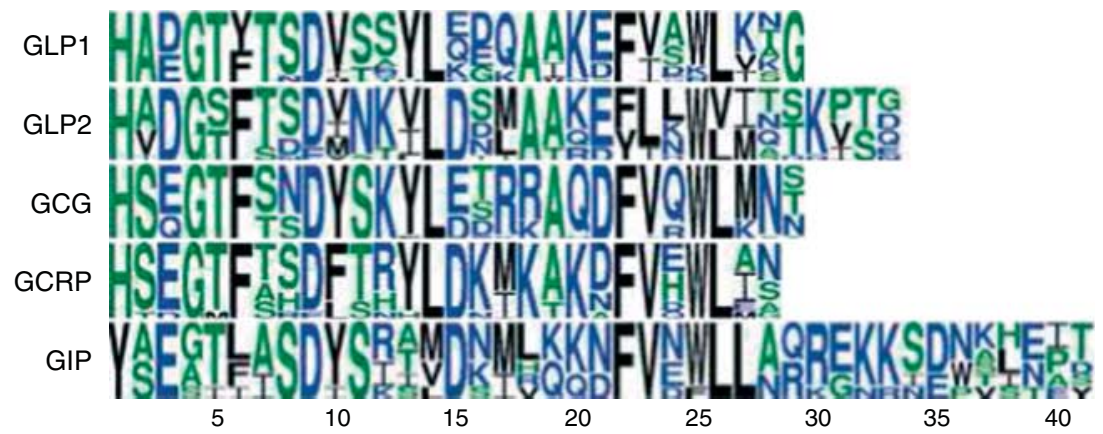

\section{Figure 4}

General structure of GLP1 and sequence alignment of GLP1 and related peptides. (A) General structure of GLP1 and functional residues. The biologically active GLP1 consists of a random coiled N-terminus with six residues followed by an $\alpha$-helix starting from Thr-7 to Val-27. The residues, His-1, Gly-4, Phe-6, Thr-7, and Asp-9 are known to be important for receptor core domain binding and activation. Residues Phe- 6 , Thr-7, and Val-10 form a helix N-capping structure. The residues, Ala-18, Ala-19, Lys-20, Phe-22, Ile-23, and Leu-26 in the second half of the $\alpha$-helix are

structures (Sherwood et al. 2000), each peptide ligand selectively interacts with its own cognate receptor, indicating that this diversification is particularly important for selective interaction of the ligand-receptor pair, resulting in the specific physiological functions of each peptide-receptor pair (Moon et al. 2012b, Park et al. 2013).

In the N-terminal part of GPL1, residues His-1, Gly-4, Phe-6, Thr-7, and Asp-9 are crucial either for maintaining secondary structure of the peptide or for interaction with the receptor (Adelhorst et al. 1994, Gallwitz et al. 1994). Particularly, Gly-4, Phe-6, and Asp/Glu-9 are highly conserved for all GLP1 and related peptides (Fig. 4B), such that these residues in the related peptides are commonly important for recognition of their cognate receptors, particularly the core domain of the receptor (Perret et al. 2002, Hinke et al. 2003, Runge et al. 2003a, Yaqub et al. 2010). His-1 and Thr/Ser-7 are conserved in the GLP1 family of peptides (GLP1, GLP2, GCG, and GCRP) except for GIP that has Tyr-1 and Ile-7 in the corresponding sites (Fig. 4B), raising a possibility that demonstrated to have direct interaction with the N-terminal ECD of the receptor. Ala- 2 is the target site of the dipeptidyl peptidase IV (DPPIV) protease and Gly-16 is involved in kinking of the $\alpha$-helix in the ECD-bound structure. (B) Sequence logo of GLP1 and its related peptides. The amino acid sequences of the orthologous peptides were analyzed using a WebLogo program (http://weblogo.threeplusone.com/create.cgi). Sequences were retrieved from human, mouse, chicken, anole lizard, Xenopus, zebrafish, medaka, stickleback, tetraodon, and fugu.

His-1 and Thr-7 of GLP1 are likely important for selective interaction with GLP1R, but discriminate GIPR. Indeed, introducing His- 1 and Thr-7 into GIP allows this chimeric peptide to bind and activate GLP1R with a relatively high affinity and potency (Moon et al. 2010, 2012a). In contrast, Tyr-1 and Ile-7 in GIPR are important for selective interactions with its receptor. In addition to Tyr- 1 and Ile-7, alanine scanning or amino acid modification studies reveal that highly conserved residues Glu-3, Gly-4, Asp-9, and Asp-15 are found to be important for receptor activation (Hinke et al. 2003, Yaqub et al. 2010). In GCG, besides the highly common residues Gly-4, Phe-6, The-7, and Asp/Glu-9 and GCG-specific residues Ser-2, Gln-3, Tyr-10, and Lys-12 (Fig. 4B) are found to be important for receptor binding and activation (Perret et al. 2002, Runge et al. 2003a). Interestingly, introducing these individual residues into the equivalent positions of GLP1 did not significantly alter peptide affinity and potency towards GLP1R. However, the replacement of these residues in GCG with those of GLP1 greatly reduced GCGR affinity

Published by Bioscientifica Ltd 
(Runge et al. 2003a), indicating that positions 2, 3, 10, and 12 are only important for GCG. This result is consistent with the observation that wild-type (WT) or chimeric peptides having either the GCG or GLP1 N-terminus interact with receptors having the GLP1R core domain while WT or chimeric peptide containing the GLP1 $\mathrm{N}$-terminus poorly binds or activates receptors containing the GCGR core domain (Runge et al. 2003b). The structureactivity relationships of GLP2 have not been extensively analyzed. However, an alanine scanning analysis revealed that residues at positions $2,5,6$, and 17 were important for receptor activation (DaCambra et al. 2000).

A recent observation, after comparing amino acid sequences of the GLP1 peptide family including a novel GCRP, indicates that residues at positions 16-18 exhibited ortholog-specific amino acid changes, such that the Lys16-Met/Ile-17-Lys-18, Ser/Thr-16-Arg-17-Arg-18, and Gly/Asp-16-Gln-17-Ala-18 motifs were conserved in GCRP, GCG, and GLP1 respectively (Park et al. 2013). Interestingly, placing the Gly/Asp-16-Gln-17-Ala-18 motif in GCRP increased peptide potency toward the WT GLP1R and GCRPR chimeric receptor that has the GLP1R core domain (Park et al. 2013). This observation raises the possibility that the motif at positions $16-18$ may contribute to selective interactions with their cognate receptors. This motif resides at the border between residues that interact with the ECD and residues that contact the core domain. Particularly, Gly-16 of GLP1 contributes to the formation of a kink in the peptide helix (Underwood et al. 2010). Thus, this motif can be proposed to be involved in interaction between ECD and the core domain under ligand-bound conditions. A recent study has proposed that the ECD of GCGR is likely to negatively regulate GCGR activity through interaction with extracellular loop 3 (ECL3) of the core domain (Koth et al. 2012).

As ligand-bound crystal structures of the core domain of the GLP1R family are not available, the residues in the core domains responsible for ligand binding or receptor activation are poorly understood, although many approaches, such as alanine scanning, photoaffinity labeling, and molecular docking modeling have been attempted to identify these specific amino acid residues (Xiao et al. 2000, Lopez de Maturana \& Donnelly 2002, Lopez de Maturana et al. 2004, Chen et al. 2009, 2010, Lin $\&$ Wang 2009). Mutation mapping studies suggest that charged amino acids (Lys-197, Asp-198, Lys-202, Asp-215, Arg-227, and Lys-288) and conserved residues (Met-204, Tyr-205, and Trp-306) are likely important for GLP1induced receptor activation (Xiao et al. 2000, Lopez de Maturana \& Donnelly 2002, Al-Sabah \& Donnelly 2003,
Lopez de Maturana et al. 2004, Koole et al. 2012). However, these studies do not explain how individual residues of the peptide interact with residues in the receptor. Our recent study reveals that His-1 and Thr-7 were found to interact with Asn-302 at ECL2 and Ile-196 at the upper half of transmembrane helix 2 (TMH2) in GLP1R respectively (Moon et al. 2012a). Interestingly, Asn-302 is conserved for all vertebrate GLP1R, and at corresponding positions in GCGR (Asn-300 for human), GLP2R (Asn-336 for human), and GCRPR (Asn-301 for chicken), that are activated by peptide ligands containing His-1. GIPR, however, has hydrophobic Val-293 at this position (Moon et al. 2012b). Likewise, all receptors interacting with Thr-7-containing peptides have conserved hydrophobic Ile or Val at the corresponding position of Ile-196 in GLP1R, while GIPR has Ser-189 in this position. The study using photolabile probes of GLP1 provided only partial information on spatial approximation of interacting residues of the peptide and receptor (Chen et al. 2010). Molecular docking modeling with biochemical analyses has proposed the ligand-binding pockets in the GLP1R core domain (Lin \& Wang 2009, Coopman et al. 2011, Kirkpatrick et al. 2012). However, these modeling approaches failed to provide a common consensus of the ligand-binding pocket such that ligand contact residues in the binding pocket are all different from one another. Thus, stricter biochemical analyses with an appropriate strategy may be helpful to construct a more reliable ligand-bound receptor model.

\section{Interaction between the peptide C-terminus and the receptor ECD}

Interactions between the peptide C-terminus and the receptor ECD are well defined for GLP1R and GIPR as demonstrated by ligand-bound ECD crystal structures (Parthier et al. 2007, Runge et al. 2008, Underwood et al. 2010). In addition, these crystal structures were useful in understanding interactions between GCG and the GCGR ECD and between GLP2 and the GLP2R ECD by applying molecular docking models (Venneti \& Hewage 2011, Koth et al. 2012, Siu et al. 2013). The crystal structure of the ligand-bound ECD of the receptors shows that only residues in the second half of the $\alpha$-helix (ranging from Ala-18 to Val-29 for GLP1) interact with the ECD (Underwood et al. 2010). The $\alpha$-helices of all peptide hormones are partly amphipathic allowing hydrophobic and hydrophilic interactions with ECD of their receptor. The hydrophobic face (Ala-18, Ala-19, Phe-22, Ile-23, Trp-25, and Leu-26) of GLP1 is toward the hydrophobic binding cavity of the ECD that is formed by residues

Published by Bioscientifica Ltd 
Leu-32, Thr-35, Val-36, and Trp-39 in the N-terminal $\alpha$-helix, residues Tyr-69 at the end of the $\beta 2$ strand, and residues Try-88, Leu-89, Trp-91, and Pro-90 in the loop between the $\beta 3$ and $\beta 4$ strands (Runge et al. 2008, Underwood et al. 2010). Many of the residues in the binding pocket are highly conserved in the equivalent positions of GIPR, GLP2R, and GCGR and they are found to be important for peptide binding (Parthier et al. 2007, Venneti \& Hewage 2011, Koth et al. 2012). Considering that residues Ala-19, Phe-22, Ile-23, and Leu-26 in the hydrophobic face of the peptides are also highly conserved, this result suggests that these evolutionarily conserved residues in the peptides and receptors are likely to contribute to primary binding between the $\alpha$-helical domain of the peptides and the ECD of the receptors (Parthier et al. 2007, Underwood et al. 2010, Venneti \& Hewage 2011, Koth et al. 2012). This primary interaction may explain crossinteractions of peptides with other receptors in the same family. For example, the GLP1 chimeric peptides having the $\alpha$-helical region of GIP or GCG are able to activate GLP1R with a relatively high potency (Runge et al. 2003a,b, Moon et al. 2010). The hydrophilic face of GLP1 comprises residues Gln-17, Lys-20, Glu-21, and Lys-28. Of these residues, only Lys-20 was found to make a direct interaction with the ECD residue Glu-128 (Underwood et al. 2010). At positions 17-20, including the hydrophilic residues, GLP1 and its related peptides exhibited marked variations in amino acid sequence, raising a possibility that selective recognition of the peptide toward the cognate ECD can be achieved through interactions of these ortholog-specific residues of the $\alpha$-helix with specific residues in the ECD of the cognate receptor (Parthier et al. 2007, Underwood et al. 2010).

\section{Conclusions}

GLP1 and GLP1R have emerged through 2R and local duplications before and after 2R. The exon duplication events also contributed to occurrence of the GLP1 peptide. Because the GLP1 peptide and receptor families arose from a common ancestor, they share similarities in their amino acid sequences and basic structures. Their conserved residues and structural similarities across the family members suggest a common mechanism underlying ligand-receptor binding followed by receptor activation. The comparison of ligand-receptor interaction mechanisms reveals that the conserved residues among GLP1 and related peptides tend to interact with conserved residues of GLP1R and its paralogous receptors (Moon et al. $2012 b$ ). Specific change after genome/gene/exon duplication may allow selective interaction of each ligand- receptor pair, and could provide for diversified functions. Our recent studies have demonstrated that interactions between residues evolved from ortholog-specific peptides and receptors enhanced recognition of a peptide for the cognate receptor, while maintaining discrimination by other receptors (Moon et al. 2010, 2012a). During the evolutionary process, GLP1, through its specific interaction with GLP1R, acquired a particular function in glucose homeostasis and appetite regulation. Although GLP1 has gained great attention due to its beneficial effects on type 2 diabetes and obesity, molecular interaction with its receptor is not fully understood. Particularly, the specific amino acid residues within the TMH and ECL of receptors that may confer ligand binding and receptor activation remain poorly investigated. Understanding the evolutionary history of GLP1/GLP1R can provide clues to explore molecular interaction properties between GLP1 and GLP1R. Elucidation of the structure of the ligandbinding pocket in the core domain of GLP1R may facilitate development of potent peptide agonists or small molecules capable of activating GLP1R, which could greatly contribute to the treatment of diabetes and obesity.

\section{Declaration of interest}

The authors declare that there is no conflict of interest that could be perceived as prejudicing the impartiality of the review.

\section{Funding}

This work was supported by grants from the Brain Research Program (2011-0019205) and Basic Research Program (2010-0022054) of the National Research Foundation of Korea (NRF) funded by the Ministry of Science, ICT and Future Planning

\section{References}

Abi-Rached L, Gilles A, Shiina T, Pontarotti P \& Inoko H 2002 Evidence of en bloc duplication in vertebrate genomes. Nature Genetics 31 100-105. (doi:10.1038/ng855)

Acharjee S, Do-Rego JL, Oh DY, Ahn RS, Choe H, Vaudry H, Kim K, Seong JY \& Kwon HB 2004 Identification of amino acid residues that direct differential ligand selectivity of mammalian and nonmammalian V1a type receptors for arginine vasopressin and vasotocin. Insights into molecular coevolution of V1a type receptors and their ligands. Journal of Biological Chemistry 279 54445-54453. (doi:10.1074/jbc. M408909200)

Adelhorst K, Hedegaard BB, Knudsen LB \& Kirk O 1994 Structure-activity studies of glucagon-like peptide-1. Journal of Biological Chemistry 269 6275-6278.

Alana I, Malthouse JP, O’Harte FP \& Hewage CM 2007 The bioactive conformation of glucose-dependent insulinotropic polypeptide by NMR and CD spectroscopy. Proteins 68 92-99. (doi:10.1002/prot. 21372)

Published by Bioscientifica Ltd 
Al-Sabah S \& Donnelly D 2003 A model for receptor-peptide binding at the glucagon-like peptide-1 (GLP-1) receptor through the analysis of truncated ligands and receptors. British Journal of Pharmacology 140 339-346. (doi:10.1038/sj.bjp.0705453)

Alvarez E, Martinez MD, Roncero I, Chowen JA, Garcia-Cuartero B, Gispert JD, Sanz C, Vazquez P, Maldonado A, de Caceres J et al. 2005 The expression of GLP-1 receptor mRNA and protein allows the effect of GLP-1 on glucose metabolism in the human hypothalamus and brainstem. Journal of Neurochemistry 92 798-806. (doi:10.1111/j.14714159.2004.02914.x)

Baggio LL \& Drucker DJ 2002 Harnessing the therapeutic potential of glucagon-like peptide-1: a critical review. Treatments in Endocrinology 1 117-125. (doi:10.2165/00024677-200201020-00005)

Cardoso JC, Pinto VC, Vieira FA, Clark MS \& Power DM 2006 Evolution of secretin family GPCR members in the metazoa. BMC Evolutionary Biology 6 108. (doi:10.1186/1471-2148-6-108)

Cardoso JC, Vieira FA, Gomes AS \& Power DM 2010 The serendipitous origin of chordate secretin peptide family members. BMC Evolutionary Biology 10 135. (doi:10.1186/1471-2148-10-135)

Chen Q, Pinon DI, Miller LJ \& Dong M 2009 Molecular basis of glucagon-like peptide 1 docking to its intact receptor studied with carboxyl-terminal photolabile probes. Journal of Biological Chemistry 284 34135-34144. (doi:10.1074/jbc.M109.038109)

Chen Q, Pinon DI, Miller LJ \& Dong M 2010 Spatial approximations between residues 6 and 12 in the amino-terminal region of glucagonlike peptide 1 and its receptor: a region critical for biological activity. Journal of Biological Chemistry 285 24508-24518. (doi:10.1074/jbc. M110.135749)

Cho HJ, Acharjee S, Moon MJ, Oh DY, Vaudry H, Kwon HB \& Seong JY 2007 Molecular evolution of neuropeptide receptors with regard to maintaining high affinity to their authentic ligands. General and Comparative Endocrinology 153 98-107. (doi:10.1016/j.ygcen.2006.12.013)

Coopman K, Wallis R, Robb G, Brown AJ, Wilkinson GF, Timms D \& Willars GB 2011 Residues within the transmembrane domain of the glucagon-like peptide-1 receptor involved in ligand binding and receptor activation: modelling the ligand-bound receptor. Molecular Endocrinology 25 1804-1818. (doi:10.1210/me.2011-1160)

DaCambra MP, Yusta B, Sumner-Smith M, Crivici A, Drucker DJ \& Brubaker PL 2000 Structural determinants for activity of glucagon-like peptide-2. Biochemistry 39 8888-8894. (doi:10.1021/bi000497p)

Drucker DJ 2003 Glucagon-like peptides: regulators of cell proliferation, differentiation, and apoptosis. Molecular Endocrinology 17 161-171. (doi:10.1210/me.2002-0306)

Drucker DJ, Philippe J, Mojsov S, Chick WL \& Habener JF 1987 Glucagonlike peptide I stimulates insulin gene expression and increases cyclic AMP levels in a rat islet cell line. PNAS 84 3434-3438. (doi:10.1073/ pnas.84.10.3434)

During MJ, Cao L, Zuzga DS, Francis JS, Fitzsimons HL, Jiao X, Bland RJ, Klugmann M, Banks WA, Drucker DJ et al. 2003 Glucagon-like peptide-1 receptor is involved in learning and neuroprotection. Nature Medicine 9 1173-1179. (doi:10.1038/nm919)

Fehmann HC \& Habener JF 1992 Insulinotropic hormone glucagon-like peptide-I(7-37) stimulation of proinsulin gene expression and proinsulin biosynthesis in insulinoma $\beta$ TC-1 cells. Endocrinology 130 159-166. (doi:10.1210/en.130.1.159)

Fehmann HC, Goke R \& Goke B 1995 Cell and molecular biology of the incretin hormones glucagon-like peptide-I and glucose-dependent insulin releasing polypeptide. Endocrine Reviews 16 390-410.

Fredriksson R, Lagerstrom MC, Lundin LG \& Schioth HB 2003 The G-protein-coupled receptors in the human genome form five main families. Phylogenetic analysis, paralogon groups, and fingerprints. Molecular Pharmacology 63 1256-1272. (doi:10.1124/mol.63.6.1256)

Gallwitz B, Witt M, Paetzold G, Morys-Wortmann C, Zimmermann B, Eckart K, Folsch UR \& Schmidt WE 1994 Structure/activity characterization of glucagon-like peptide-1. European Journal of Biochemistry 225 1151-1156. (doi:10.1111/j.1432-1033.1994.1151b.x)
Grace CR, Perrin MH, DiGruccio MR, Miller CL, Rivier JE, Vale WW \& Riek R 2004 NMR structure and peptide hormone binding site of the first extracellular domain of a type B1 G protein-coupled receptor. PNAS 101 12836-12841. (doi:10.1073/pnas.0404702101)

Graziano MP, Hey PJ, Borkowski D, Chicchi GG \& Strader CD 1993 Cloning and functional expression of a human glucagon-like peptide-1 receptor. Biochemical and Biophysical Research Communications 196 141-146. (doi:10.1006/bbrc.1993.2226)

Hansotia T \& Drucker DJ 2005 GIP and GLP-1 as incretin hormones: lessons from single and double incretin receptor knockout mice. Regulatory Peptides 128 125-134. (doi:10.1016/j.regpep.2004.07.019)

Harmar AJ 2001 Family-B G-protein-coupled receptors. Genome Biology 2 REVIEWS3013. (doi:10.1186/gb-2001-2-12-reviews3013)

Hewes RS \& Taghert PH 2001 Neuropeptides and neuropeptide receptors in the Drosophila melanogaster genome. Genome Research 11 1126-1142. (doi:10.1101/gr.169901)

Hinke SA, Gelling R, Manhart S, Lynn F, Pederson RA, Kuhn-Wache K, Rosche F, Demuth HU, Coy D \& McIntosh CH 2003 Structure-activity relationships of glucose-dependent insulinotropic polypeptide (GIP). Biological Chemistry 384 403-407. (doi:10.1515/BC.2003.046)

Hisadome K, Reimann F, Gribble FM \& Trapp S 2010 Leptin directly depolarizes preproglucagon neurons in the nucleus tractus solitarius: electrical properties of glucagon-like peptide 1 neurons. Diabetes $\mathbf{5 9}$ 1890-1898. (doi:10.2337/db10-0128)

Holland PW 2003 More genes in vertebrates? Journal of Structural and Functional Genomics 3 75-84. (doi:10.1023/A:1022656931587)

Hwang JI, Moon MJ, Park S, Kim DK, Cho EB, Ha N, Son GH, Kim K, Vaudry H \& Seong JY 2013 Expansion of secretin-like G proteincoupled receptors and their peptide ligands via local duplications before and after two rounds of whole-genome duplication. Molecular Biology and Evolution 30 1119-1130. (doi:10.1093/molbev/mst031)

Irwin DM \& Prentice KJ 2011 Incretin hormones and the expanding families of glucagon-like sequences and their receptors. Diabetes, Obesity \& Metabolism 13 (Suppl 1) 69-81. (doi:10.1111/j.1463-1326. 2011.01444.x)

Irwin DM \& Wong K 2005 Evolution of new hormone function: loss and gain of a receptor. Journal of Heredity 96 205-211. (doi:10.1093/jhered/ esi024)

Irwin DM, Satkunarajah M, Wen Y, Brubaker PL, Pederson RA \& Wheeler MB 1997 The Xenopus proglucagon gene encodes novel GLP-1like peptides with insulinotropic properties. PNAS 94 7915-7920. (doi:10.1073/pnas.94.15.7915)

Irwin DM, Huner O \& Youson JH 1999 Lamprey proglucagon and the origin of glucagon-like peptides. Molecular Biology and Evolution 16 1548-1557. (doi:10.1093/oxfordjournals.molbev.a026067)

Ishihara T, Nakamura S, Kaziro Y, Takahashi T, Takahashi K \& Nagata S 1991 Molecular cloning and expression of a cDNA encoding the secretin receptor. EMBO Journal 10 1635-1641.

Kang G, Chepurny OG \& Holz GG 2001 cAMP-regulated guanine nucleotide exchange factor II (Epac2) mediates $\mathrm{Ca}^{2+}$-induced $\mathrm{Ca}^{2+}$ release in INS-1 pancreatic $\beta$-cells. Journal of Physiology 536 375-385. (doi:10.1111/j.1469-7793.2001.0375c.xd)

Kieffer TJ \& Habener JF 1999 The glucagon-like peptides. Endocrine Reviews 20 876-913. (doi:10.1210/er.20.6.876)

Kim DK, Cho EB, Moon MJ, Park S, Hwang JI, Kah O, Sower SA, Vaudry H \& Seong JY 2011 Revisiting the evolution of gonadotropin-releasing hormones and their receptors in vertebrates: secrets hidden in genomes. General and Comparative Endocrinology 170 68-78. (doi:10.1016/j.ygcen.2010.10.018)

Kim DK, Cho EB, Moon MJ, Park S, Hwang JI, Do Rego JL, Vaudry H \& Seong JY 2012 Molecular coevolution of neuropeptides gonadotropin-releasing hormone and kisspeptin with their cognate $\mathrm{G}$ protein-coupled receptors. Frontiers in Neuroscience 6 3. (doi:10.3389/ fnins.2012.00003)

Kirkpatrick A, Heo J, Abrol R \& Goddard WA III 2012 Predicted structure of agonist-bound glucagon-like peptide 1 receptor, a class B G protein-

Published by Bioscientifica Ltd 
coupled receptor. PNAS 109 19988-19993. (doi:10.1073/pnas. 1218051109)

Koole C, Wootten D, Simms J, Miller LJ, Christopoulos A \& Sexton PM 2012 Second extracellular loop of human glucagon-like peptide-1 receptor (GLP-1R) has a critical role in GLP-1 peptide binding and receptor activation. Journal of Biological Chemistry 287 3642-3658. (doi:10.1074/ jbc.M111.309328)

Koth CM, Murray JM, Mukund S, Madjidi A, Minn A, Clarke HJ, Wong T, Chiang V, Luis E, Estevez A et al. 2012 Molecular basis for negative regulation of the glucagon receptor. PNAS 109 14393-14398. (doi:10.1073/pnas.1206734109)

Laburthe M, Couvineau A, Gaudin P, Maoret JJ, Rouyer-Fessard C \& Nicole P 1996 Receptors for VIP, PACAP, secretin, GRF, glucagon, GLP-1, and other members of their new family of $\mathrm{G}$ protein-linked receptors: structure-function relationship with special reference to the human VIP-1 receptor. Annals of the New York Academy of Sciences 805 94-109 (discussion 110-111). (doi:10.1111/j.1749-6632.1996.tb17476.x)

Larhammar D, Lundin LG \& Hallbook F 2002 The human Hox-bearing chromosome regions did arise by block or chromosome (or even genome) duplications. Genome Research 12 1910-1920. (doi:10.1101/ gr.445702)

Lee YR, Tsunekawa K, Moon MJ, Um HN, Hwang JI, Osugi T, Otaki N, Sunakawa Y, Kim K, Vaudry H et al. 2009 Molecular evolution of multiple forms of kisspeptins and GPR54 receptors in vertebrates. Endocrinology 150 2837-2846. (doi:10.1210/en.2008-1679)

Li Y, Hansotia T, Yusta B, Ris F, Halban PA \& Drucker DJ 2003 Glucagon-like peptide-1 receptor signaling modulates $\beta$ cell apoptosis. Journal of Biological Chemistry 278 471-478. (doi:10.1074/jbc.M209423200)

Li JH, Choe H, Wang AF, Maiti K, Wang C, Salam A, Chun SY, Lee WK, Kim K, Kwon HB et al. 2005 Extracellular loop 3 (EL3) and EL3-proximal transmembrane helix 7 of the mammalian type I and type II gonadotropin-releasing hormone $(\mathrm{GnRH})$ receptors determine differential ligand selectivity to GnRH-I and GnRH-II. Molecular Pharmacology 67 1099-1110. (doi:10.1124/mol.104.004887)

Lin F \& Wang R 2009 Molecular modeling of the three-dimensional structure of GLP-1R and its interactions with several agonists. Journal of Molecular Modeling 15 53-65. (doi:10.1007/s00894-008-0372-2)

Lopez de Maturana R \& Donnelly D 2002 The glucagon-like peptide-1 receptor binding site for the N-terminus of GLP-1 requires polarity at Asp198 rather than negative charge. FEBS Letters 530 244-248. (doi:10.1016/S0014-5793(02)03492-0)

Lopez de Maturana R, Treece-Birch J, Abidi F, Findlay JB \& Donnelly D 2004 Met-204 and Tyr-205 are together important for binding GLP-1 receptor agonists but not their N-terminally truncated analogues. Protein and Peptide Letters 11 15-22. (doi:10.2174/ 0929866043478491)

Mirabeau O \& Joly JS 2013 Molecular evolution of peptidergic signaling systems in bilaterians. PNAS 110 E2028-E2037. (doi:10.1073/pnas. 1219956110)

Mojsov S, Heinrich G, Wilson IB, Ravazzola M, Orci L \& Habener JF 1986 Preproglucagon gene expression in pancreas and intestine diversifies at the level of post-translational processing. Journal of Biological Chemistry 261 11880-11889.

Mojsov S, Kopczynski MG \& Habener JF 1990 Both amidated and nonamidated forms of glucagon-like peptide I are synthesized in the rat intestine and the pancreas. Journal of Biological Chemistry $\mathbf{2 6 5}$ 8001-8008.

Moon MJ, Kim HY, Kim SG, Park J, Choi DS, Hwang JI \& Seong JY 2010 Tyr1 and Ile7 of glucose-dependent insulinotropic polypeptide (GIP) confer differential ligand selectivity toward GIP and glucagon-like peptide-1 receptors. Molecules and Cells 30 149-154. (doi:10.1007/s10059-0100100-5)

Moon MJ, Kim HY, Park S, Kim DK, Cho EB, Hwang JI \& Seong JY 2011 Insulin contributes to fine-tuning of the pancreatic $\beta$-cell response to glucagon-like peptide-1. Molecules and Cells 32 389-395. (doi:10.1007/ s10059-011-0157-9)
Moon MJ, Kim HY, Park S, Kim DK, Cho EB, Park CR, You DJ, Hwang JI, Kim K, Choe $\mathrm{H}$ et al. 2012a Evolutionarily conserved residues at glucagon-like peptide-1 (GLP-1) receptor core confer ligand-induced receptor activation. Journal of Biological Chemistry 287 3873-3884. (doi:10.1074/jbc.M111.276808)

Moon MJ, Park S, Kim DK, Cho EB, Hwang JI, Vaudry H \& Seong JY $2012 b$ Structural and molecular conservation of glucagon-like peptide-1 and its receptor confers selective ligand-receptor interaction. Frontiers in Endocrinology 3 141. (doi:10.3389/fendo.2012.00141)

Nakatani Y, Takeda H, Kohara Y \& Morishita S 2007 Reconstruction of the vertebrate ancestral genome reveals dynamic genome reorganization in early vertebrates. Genome Research 17 1254-1265. (doi:10.1101/ gr.6316407)

Nauck MA, Heimesaat MM, Behle K, Holst JJ, Nauck MS, Ritzel R, Hufner M \& Schmiegel WH 2002 Effects of glucagon-like peptide 1 on counterregulatory hormone responses, cognitive functions, and insulin secretion during hyperinsulinemic, stepped hypoglycemic clamp experiments in healthy volunteers. Journal of Clinical Endocrinology and Metabolism 87 1239-1246. (doi:10.1210/jc.87.3.1239)

Neidigh JW, Fesinmeyer RM, Prickett KS \& Andersen NH 2001 Exendin-4 and glucagon-like-peptide-1: NMR structural comparisons in the solution and micelle-associated states. Biochemistry 40 13188-13200. (doi:10.1021/bi010902s)

Neumann JM, Couvineau A, Murail S, Lacapere JJ, Jamin N \& Laburthe M 2008 Class-B GPCR activation: is ligand helix-capping the key? Trends in Biochemical Sciences 33 314-319. (doi:10.1016/j.tibs.2008.05.001)

Ng SY, Chow BK, Kasamatsu J, Kasahara M \& Lee LT 2012 Agnathan VIP, PACAP and their receptors: ancestral origins of today's highly diversified forms. PLoS ONE 7 e44691. (doi:10.1371/journal.pone. 0044691)

Nguyen TM, Mommsen TP, Mims SM \& Conlon JM 1994 Characterization of insulins and proglucagon-derived peptides from a phylogenetically ancient fish, the paddlefish (Polyodon spathula). Biochemical Journal 300 339-345.

Nordstrom KJ, Fredriksson R \& Schioth HB 2008 The amphioxus (Branchiostoma floridae) genome contains a highly diversified set of $\mathrm{G}$ protein-coupled receptors. BMC Evolutionary Biology 8 9. (doi:10.1186/ 1471-2148-8-9)

Oh DY, Kim K, Kwon HB \& Seong JY 2006 Cellular and molecular biology of orphan $\mathrm{G}$ protein-coupled receptors. International Review of Cytology 252 163-218.

Park CR, Moon MJ, Park S, Kim D-K, Cho EB, Millar RP, Hwang J-I \& Seong JY 2013 A novel glucagon-related peptide (GCRP) and its receptor GCRPR account for coevolution of their family members in vertebrates. PLoS ONE 8 e65420. (doi:10.1371/journal.pone.0065420)

Parthier C, Kleinschmidt M, Neumann P, Rudolph R, Manhart S, Schlenzig D, Fanghanel J, Rahfeld JU, Demuth HU \& Stubbs MT 2007 Crystal structure of the incretin-bound extracellular domain of a $G$ protein-coupled receptor. PNAS 104 13942-13947. (doi:10.1073/pnas. 0706404104)

Perret J, Van Craenenbroeck M, Langer I, Vertongen P, Gregoire F, Robberecht P \& Waelbroeck M 2002 Mutational analysis of the glucagon receptor: similarities with the vasoactive intestinal peptide (VIP)/pituitary adenylate cyclase-activating peptide (PACAP)/secretin receptors for recognition of the ligand's third residue. Biochemical Journal 362 389-394. (doi:10.1042/0264-6021:3620389)

Perry T, Holloway HW, Weerasuriya A, Mouton PR, Duffy K, Mattison JA \& Greig NH 2007 Evidence of GLP-1-mediated neuroprotection in an animal model of pyridoxine-induced peripheral sensory neuropathy. Experimental Neurology 203 293-301. (doi:10.1016/j.expneurol.2006. 09.028)

Putnam NH, Butts T, Ferrier DE, Furlong RF, Hellsten U, Kawashima T, Robinson-Rechavi M, Shoguchi E, Terry A, Yu JK et al. 2008 The amphioxus genome and the evolution of the chordate karyotype. Nature 453 1064-1071. (doi:10.1038/nature06967) 
Runge S, Gram C, Brauner-Osborne H, Madsen K, Knudsen LB \& Wulff BS $2003 a$ Three distinct epitopes on the extracellular face of the glucagon receptor determine specificity for the glucagon amino terminus. Journal of Biological Chemistry 278 28005-28010. (doi:10.1074/jbc. M301085200)

Runge S, Wulff BS, Madsen K, Brauner-Osborne H \& Knudsen LB 2003b Different domains of the glucagon and glucagon-like peptide-1 receptors provide the critical determinants of ligand selectivity. British Journal of Pharmacology 138 787-794. (doi:10.1038/sj.bjp.0705120)

Runge S, Thogersen H, Madsen K, Lau J \& Rudolph R 2008 Crystal structure of the ligand-bound glucagon-like peptide-1 receptor extracellular domain. Journal of Biological Chemistry 283 11340-11347. (doi:10.1074/ jbc.M708740200)

Santini S, Boore JL \& Meyer A 2003 Evolutionary conservation of regulatory elements in vertebrate Hox gene clusters. Genome Research $\mathbf{1 3}$ 1111-1122. (doi:10.1101/gr.700503)

Schmidt WE, Siegel EG \& Creutzfeldt W 1985 Glucagon-like peptide-1 but not glucagon-like peptide-2 stimulates insulin release from isolated rat pancreatic islets. Diabetologia 28 704-707. (doi:10.1007/BF00291980)

Sherwood NM, Krueckl SL \& McRory JE 2000 The origin and function of the pituitary adenylate cyclase-activating polypeptide (PACAP)/glucagon superfamily. Endocrine Reviews 21 619-670. (doi:10.1210/er.21.6.619)

Siu FY, He M, de Graaf C, Han GW, Yang D, Zhang Z, Zhou C, Xu Q, Wacker D, Joseph JS et al. 2013 Structure of the human glucagon class B G-protein-coupled receptor. Nature 499 444-449. (doi:10.1038/ nature12393)

Thornton K \& Gorenstein DG 1994 Structure of glucagon-like peptide (7-36) amide in a dodecylphosphocholine micelle as determined by $2 \mathrm{D}$ NMR. Biochemistry 33 3532-3539. (doi:10.1021/bi00178a009)

Underwood CR, Garibay P, Knudsen LB, Hastrup S, Peters GH, Rudolph R \& Reedtz-Runge S 2010 Crystal structure of glucagon-like peptide-1 in complex with the extracellular domain of the glucagon-like peptide-1 receptor. Journal of Biological Chemistry 285 723-730. (doi:10.1074/jbc. M109.033829)

Venneti KC \& Hewage CM 2011 Conformational and molecular interaction studies of glucagon-like peptide- 2 with its N-terminal extracellular receptor domain. FEBS Letters 585 346-352. (doi:10.1016/ j.febslet.2010.12.011)

Vienne A, Rasmussen J, Abi-Rached L, Pontarotti P \& Gilles A 2003 Systematic phylogenomic evidence of en bloc duplication of the ancestral 8p11.21-8p21.3-like region. Molecular Biology and Evolution 20 1290-1298. (doi:10.1093/molbev/msg127)

Vrang N, Hansen M, Larsen PJ \& Tang-Christensen M 2007 Characterization of brainstem preproglucagon projections to the paraventricular and dorsomedial hypothalamic nuclei. Brain Research 1149 118-126. (doi:10.1016/j.brainres.2007.02.043)
Wang C, Yun O, Maiti K, Oh DY, Kim KK, Chae CH, Lee CJ, Seong JY \& Kwon HB 2004 Position of Pro and Ser near Glu7.32 in the extracellular loop 3 of mammalian and nonmammalian gonadotropinreleasing hormone $(\mathrm{GnRH})$ receptors is a critical determinant for differential ligand selectivity for mammalian GnRH and chicken GnRH-II. Molecular Endocrinology 18 105-116. (doi:10.1210/ me.2003-0101)

Wang Y, Li J, Wang CY, Kwok AY, Zhang X \& Leung FC 2010 Characterization of the receptors for chicken GHRH and GHRH-related peptides: identification of a novel receptor for GHRH and the receptor for GHRH-LP (PRP). Domestic Animal Endocrinology 38 13-31. (doi:10.1016/j.domaniend.2009.07.008)

Wang Y, Meng F, Zhong Y, Huang G \& Li J 2012 Discovery of a novel glucagon-like peptide (GCGL) and its receptor (GCGLR) in chickens: evidence for the existence of GCGL and GCGLR genes in nonmammalian vertebrates. Endocrinology 153 5247-5260. (doi:10.1210/ en.2012-1586)

Wei Y \& Mojsov S 1995 Tissue-specific expression of the human receptor for glucagon-like peptide-I: brain, heart and pancreatic forms have the same deduced amino acid sequences. FEBS Letters 358 219-224. (doi:10.1016/0014-5793(94)01430-9)

Wheeler MB, Lu M, Dillon JS, Leng XH, Chen C \& Boyd AE III 1993 Functional expression of the rat glucagon-like peptide-I receptor, evidence for coupling to both adenylyl cyclase and phospholipase-C. Endocrinology 133 57-62. (doi:10.1210/en.133.1.57)

Xiao Q, Jeng W \& Wheeler MB 2000 Characterization of glucagon-like peptide-1 receptor-binding determinants. Journal of Molecular Endocrinology 25 321-335. (doi:10.1677/jme.0.0250321)

Xu G, Stoffers DA, Habener JF \& Bonner-Weir S 1999 Exendin-4 stimulates both $\beta$-cell replication and neogenesis, resulting in increased $\beta$-cell mass and improved glucose tolerance in diabetic rats. Diabetes $\mathbf{4 8}$ 2270-2276. (doi:10.2337/diabetes.48.12.2270)

Yaqub T, Tikhonova IG, Lattig J, Magnan R, Laval M, Escrieut C, Boulegue C, Hewage C \& Fourmy D 2010 Identification of determinants of glucosedependent insulinotropic polypeptide receptor that interact with $\mathrm{N}$-terminal biologically active region of the natural ligand. Molecular Pharmacology 77 547-558. (doi:10.1124/mol.109.060111)

Yegorov S \& Good S 2012 Using paleogenomics to study the evolution of gene families: origin and duplication history of the relaxin family hormones and their receptors. PLoS ONE 7 e32923. (doi:10.1371/ journal.pone.0032923)

Zander M, Madsbad S, Madsen JL \& Holst JJ 2002 Effect of 6-week course of glucagon-like peptide 1 on glycaemic control, insulin sensitivity, and $\beta$-cell function in type 2 diabetes: a parallel-group study. Lancet 359 824-830. (doi:10.1016/S0140-6736(02)07952-7)

Received in final form 16 October 2013

Accepted 10 December 2013 http://jme.endocrinology-journals.org DOI: 10.1530/JME-13-0137
C 2014 Society for Endocrinology Printed in Great Britain
Published by Bioscientifica Ltd 